\title{
ANALYTICAL LEGAL PHILOSOPHY RELOADED
}

\author{
FILOSOFÍA JURÍDICA ANALÍTICA RECARGADA
}

\author{
Guillermo LARIGUET*
}

\section{Resumen:}

En este ensayo defiendo que cierta forma de hacer filosofia jurídica está comprometida con una visión cerrada y parcial de concebir el quehacer filosófico. Esta visión genera una filosofia jurídica intelectualmente pobre y carente de capacidad para guiar debates sustantivos. Defiendo que el positivismo jurídico metodológico no es una buena manera de articular el desarrollo de la filosofia jurídica. Sostengo, además, que es preciso reflexionar sobre el lugar que debería ocupar la filosofia jurídica en un panorama intelectual global. Para desarrollar mis argumentos, distingo el trabajo de los filósofos del derecho juristas respecto del de los filósofos del derecho-filósofos y los filósofos-filósofos. A modo de coda, bosquejo cuáles serian los criterios que hay que revisar para concebir la filosofia jurídica analítica desde una nueva perspectiva.

Palabras clave:

Filosofia jurídica, filosofia analitica, positivismo jurídico metodológico, normatividad, metodología jurídica.

\footnotetext{
* Doctor in Law and Social Sciences, Faculty of Law, National University of Córdoba. Researcher at Conicet, IDH, UNC. Professor of Methodology of Legal and Social Research at Faculty of Law, UNC. E-mail: gclariguet@gmail.com

I am extremely grateful to René González de la Vega, David Martiinez Zorrilla and Juan Vega for their sharp observations. The defects in this text are entirely my responsibility. I also want to thank Sandra Gómora and Enrique Rodriguez for their detailed technical revision of the paper.
} 
Esta revista forma parte del acervo de la Biblioteca Jurídica Virtual del Instituto de Investigaciones Jurídicas de la UNAM

\begin{abstract}
:
In this essay I argue a particular legal philosophy is committed to a partial and closed view of how philosophical work is conceived. This view produces a legal philosophy that lacks the ability to guide substantive discussions. I argue that methodological legal positivism is not a good way to articulate the development of legal philosophy. Then, I argue that we need to consider the place that legal philosophy should occupy in the global intellectual landscape. In addition, I develop my argument by distinguishing the work of legal-philosophy jurists from that of legal-philosophy philosophers and philosophy philosophers. As a coda, I sketch the criteria in order to conceive analytical legal philosophy from a new perspective.
\end{abstract}

Keywords:

Legal Philosophy, Analytical Philosophy, Methodological Legal Positivism, Legal Normativity, Legal Methodology. 
"Toda endogamia es asfixiante, incluso los colleges, los campus universitarios, los clubes exclusivos, las clases piloto, las reuniones politicas y los simposios culturales son la negación de la vida, que es un puerto de mar".

Microcosmos, Claudio MAGRIS

"El especialista "sabe" muy bien su mínimo rincón de universo; pero ignora de raíz todo el resto".

La barbarie del especialismo. José ORTEGA Y GASSET

"Filósofo: Pero ¿qué es la justicia?

Jurista: Justicia es dar a cada uno lo suyo.

Filósofo: la definición es buena, pero es la de Aristóteles.

¿Cuál es la definición convenida como principio en la ciencia del Derecho común (common law)?

Jurista: la misma que la de Aristóteles.

Filósofo: Ved vosotros, los juristas, cuánto debéis al filósofo y con razón, pues la más noble y general ciencia y ley de todo el mundo es la verdadera filosofia, de la que el Derecho común de Inglaterra es una pequeñísima parte".

Diálogo entre un filósofo y un jurista y escritos autobiográficos, Thomas Hobbes

Summary: I. Introduction. II. Jurist Legal Philosophy, Philosopher Legal Philosophy and Philosopher Philosophy. III. The Philosophy of Law and the Global Intellectual Landscape. IV. Methodological Legal Positivism as a Theory of Law, not as a Philosophy of Law. V. Analytical Legal Philosophy Revisited. VI. Bibliography.

\section{INTRODUCTION}

My primary aim in this essay is to present a perspective of the way I believe a significant part of legal philosophy is developed. This perspective will combine a testimonial ingredient with a conceptual stance regarding the place Philoso- 
Esta revista forma parte del acervo de la Biblioteca Jurídica Virtual del Instituto de Investigaciones Jurídicas de la UNAM www.juridicas.unam.mx

http://biblio.juridicas.unam.mx

\section{GUILLERMO LARIGUET}

phy of Law should occupy in the domain of what is called practical philosophy. I would like to focus mainly, though not exclusively, on the Philosophy of Law developed by jurists, in either the Spanish-American context or the English speaking one. After presenting the state of affairs of the Philosophy of Law in the first part of the article (sections I, II and III), my second aim will consist in showing that methodological legal positivism - designed under the characteristics of the Philosophy of Law described in the first part- is incapable of accounting for the phenomenon of authority and normativity in law. I must make clear at the outset that there is no analytical link between a certain manner of teaching and transmitting the philosophy of law -which I shall describe shortly- and legal positivism. Rather I am thinking about how a certain training, linked to the decision - for whatever reason- to accept the postulates of methodological legal positivism involves an inability to account for the authority of law. I will also claim that this kind of positivism either becomes isolated from practical philosophy or has an inadequate understanding thereof. Added to this is the fact that, if legal positivism is carved out under a partial and distorted conception of analytical philosophy, it also entails a fragmented and frail understanding of law and of the place of the Philosophy of Law. I shall argue that we must once again reflect upon the best way to make conceptual analysis from the realm of practical philosophy and not from the confined walls of the legal positivist lighthouse. The lights of this lighthouse are too weak to guide sailors venturing forth into the sea of practical philosophy in an illuminating manner and tackle the problem of the authority of law.

To begin with, I would like to present a diagnosis of the theoretical situation of the discipline.

Firstly, there is a philosophy developed primarily by jurists (dogmatists of law, judges and barristers) who have borrowed philosophical tools in a fragmentary manner, often self-taught and generally ad hoc, in order to study problems they, ultimately, find urgent or interesting. Addition- 
Esta revista forma parte del acervo de la Biblioteca Jurídica Virtual del Instituto de Investigaciones Jurídicas de la UNAM www.juridicas.unam.mx

http://biblio.juridicas.unam.mx

ANALYTICAL LEGAL PHILOSOPHY RELOADED

ally, no doubt that these philosophers, during their intellectual training, before delving into philosophers such as Aristotle or Plato, Kant or Hegel, or Schelling or Fichte, Putnam or Rorty, etcetera, had to digest, over and over again, Kelsen's Pure Theory of Law, Hart's The Concept of Law or Alchourrón and Bulygin's Normative Systems. Several of these legal-philosophy jurists also understood that only philosophy made by analytical philosophers was worth reading, thus setting aside texts like those of Nietzsche, Foucault or Derrida, to give a few examples. This way of understanding philosophy, as I will argue, is pernicious and is not even required by analytical philosophy, at least not in the way I shall outline in this paper. Although I shall be dealing with this question later, it is worth to anticipate, roughly, the two reasons why I believe such a reception of analytical philosophy is pernicious. First, because it serves as a poor excuse to ignore much philosophical work that is valuable. Second, because it is a way of understanding analytical philosophy which is too narrow and not descriptive enough of the work of many philosophers we would no doubt also consider analytical.

These legal-philosophy jurists I am thinking of, also generally received a more or less systematic, more or less careful, more or less encyclopedic legal education which problematized normative materials to a greater or a lesser extent. But in most cases we are talking about philosophers who were made in schools of law rather than schools of philosophy. This partial description does not mean that philosophers who were trained in schools of philosophy cannot also become interested in law as was, in fact, the case with classical philosophers such as Kant or Hegel or, nearer to our times, philosophers as divergent as Boaventura de Sousa Santos, ${ }^{1}$

1 For example: Poderá o direito ser emancipatório?, Faculdade de Direito e Fundação Boiteux Vitória, 2007.

PROBLEMA

Anuario de Filosofia y Teoría del Derecho,

Núm. 8, enero-diciembre de 2014, pp. 3-37 
Esta revista forma parte del acervo de la Biblioteca Jurídica Virtual del Instituto de Investigaciones Jurídicas de la UNAM www.juridicas.unam.mx

http://biblio.juridicas.unam.mx

GUILLERMO LARIGUET

Slavok Zizek, ${ }^{2}$ Habermas, ${ }^{3}$ Rawls, ${ }^{4}$ Larry Laudan, ${ }^{5}$ George Henrik von Wright, ${ }^{6}$ or Jon Elster. ${ }^{7}$ But the fact remains that the description I am making appears to have given a footing to Bobbio's often used distinction between the philosophy of law of jurists and the philosophy of law of philosophers. ${ }^{8} \mathrm{~A}$ difference which, it seems, suggests a purely stylistic issue, ${ }^{9}$ but one which, despite this, does not seem invalid. While legal-philosophy jurists tackle small, concrete legal issues, legal-philosophy philosopher tend to deal with more abstract legal problems. This differentiation, on the other hand, has placed legal-philosophy jurists in the unfortunate situation of not being true philosophers, at least for some philosophers (from schools of philosophy), or, if they are, of doing nothing that seems of interest or worth taking seriously. And, for many lawyers, trained in legions of law schools, these legal-philosophy jurists are either not jurists or not lawyers and most of the things they write or teach, for example on logic, the methodology of a purported legal research project, etcetera, are manifestations of abstract, abstruse topics, unrelated to the true concerns or problems of jurists

2 El más sublime d elos histéricos, Buenos Aires, Paidós, 2011.

3 Facticidad y validez. Sobre el derecho y el estado democrático de derecho en términos de teoría del discurso, Madrid, Trotta, 1998.

4 Teoría de la justicia, trad. de María Dolores González, México, Fondo de Cultura Económica, 1995.

5 Along with Juan Antonio Cruz Parcero (comps.) Prueba y estándares de prueba en el derecho, México, UNAM, Instituto de Investigaciones Filosóficas, 2010.

6 Who, as is widely known, strongly influenced the development of deonctic logic. See Eugenio Bulygin's speech when receiving the honoris causa PhD from the University of Alicante in Academia. Revista sobre enseñanza del derecho, year 6, No. 12, 2008, pp. 319-324.

7 Juicios Salomónicos, Barcelona, Gedisa, 1998.

8 See the discussion on the distinction in Del Real Alcalá, José Alberto, "La construcción temática de la filosofia del derecho de los juristas", Problema. Anuario de Filosofía y Teoría del Derecho, México, núm. 4, 2010, pp. 169-203.

9 Guastini, Riccardo, Distinguiendo. Estudios de teoría y metateoría del derecho, Barcelona, Gedisa, 1999. 
Esta revista forma parte del acervo de la Biblioteca Jurídica Virtual del Instituto de Investigaciones Jurídicas de la UNAM www.juridicas.unam.mx

http://biblio.juridicas.unam.mx

ANALYTICAL LEGAL PHILOSOPHY RELOADED

and therefore devoid of any practical relevance. Complementing this invective against the philosophy of law, jurists -who do not philosophize- sometimes make an inverse claim directed at legal-philosophy jurists, for example: please do something about this area! 10 This claim seeks to vindicate the need for the legal-philosophy jurist, who generally descends to areas such as criminal law, and less intensely to topics related to civil law, to also tackle conceptual and normative problems that arise in areas like private international law, environmental law, agrarian law, mining law, etcetera, widely ignored by legal-philosophy philosopher.

Another predominant feature is that an important part of the activities of these legal-philosophy jurists, notwithstanding the partial inclusion of certain philosophical tools, makes their work decidedly "isolationist"11 or strongly "insular". This insularity is reinforced by two aspects. The first is related to the fact that the progress of the theory of law has been associated, starting with Kelsen, with a growing autonomy and strong delimitation of law and legal science with regard to other social disciplines. ${ }^{12}$ This epistemological process towards autonomy led to considerable conceptual clarification on topics such as the systematic structure of law or issues related to a variety of concepts of legal validity. However, this process has generated significant inconveniences. First, this process generated

10 I can witness this from my personal experience as professor of legal research methodology in the Postgraduate course in Law of the School of Law and Social Sciences of the National University of Cordoba where specialist faculty in different areas of law frequently claim this from legal philosophers.

11 Priel, Dan, "H. L. A. Hart and the Invention of Legal Philosophy", Problema. Anuario de Filosofía y Teoría del Derecho, México, núm. 5, 2011, pp. 301-323.

12 I have examined closely Kelsen's position in Chapter 1 of my Dogmática jurídica y aplicación de normas, México, Fontamara, 2007 and also in my Problemas del Conocimiento jurídico, Buenos Aires, Ediar, 2008. Moreover, in the latter text I reconstruct the philosophical-legal position of other positivists such as Ross, Alchourron and Bulygin, Tarello, etcetera. 
Esta revista forma parte del acervo de la Biblioteca Jurídica Virtual del Instituto de Investigaciones Jurídicas de la UNAM www.juridicas.unam.mx

http://biblio.juridicas.unam.mx

GUILLERMO LARIGUET

"schizophrenic" jurists or thinkers. For example, Kelsen wrote on the political theory of democracy, the theory of justice and the theory of law separately, thus breaking the communication between these areas of study. But apart from this observation of academic psychology the main problem has been the construction of a legal theory isolated from the remaining disciplines in the humanities (history, moral and political philosophy, and so on). This isolation ends up generating partial and distorted images of law, showing it as something apart from achievements made in other areas, in particular relevant practices such as moral and political philosophy. On the other hand, the isolation and insularity stem from the fact that the dialogue between legal-philosophy jurists and legal-philosophy philosophers has been unusual - to continue Bobbio's distinction- and, even less so, between legal-philosophy jurists and philosophy philosophers. Added to this, there are but a few institutional spaces for them to interact. And this is not something attributable only to legal-philosophy jurists but also to philosopher-philosophers. Their indifference to certain theoretical research on law reveals how little philosophical sensitivity they sometimes show for relevant practical issues. Law is a field where nearly all, if not all, the most relevant practical issues are posed. Perhaps this can be reinforced by what Mackie ${ }^{13}$ once stated about ethics being jurisprudence's poorer relative. This could also be reinforced by the idea once suggested by Toulmin that legal reasoning is the basis of informal logical reasoning, ${ }^{14}$ with the idea popularized by Popper ${ }^{15}$ that the tribunal of experience is similar to a court of justice in the way it operates or,

13 Mackie, John, Ética: la invención de lo bueno y lo malo, Barcelona, Gedisa, 2000.

14 Toulmin, Stephen, The Uses of Argument, Cambridge Mass., Cambridge University Press, 2003.

15 See Lariguet, Guillermo, "La aplicabilidad del programa falsacionista de Popper a la ciencia jurídica", Isonomía. Revista de Teoría del Derecho, México, núm. 17, 2002, pp. 183-202. 
Esta revista forma parte del acervo de la Biblioteca Jurídica Virtual del Instituto de Investigaciones Jurídicas de la UNAM www.juridicas.unam.mx

http://biblio.juridicas.unam.mx

ANALYTICAL LEGAL PHILOSOPHY RELOADED

lastly, with the idea that the modus operandi of analytical philosophy is similar to that of forensic argument. All these examples show that some philosophy philosophers do show a greater sensibility to law, unlike other colleagues from schools of philosophy who represent the opposite attitude.

Lastly, when legal-philosophy jurists embrace "methodological" legal positivism - though this statement could extend to legal-philosophy philosopher - they strengthen the abovementioned insularity with the thesis that conceptually separates law from morality, ${ }^{16}$ although the separation may also extend to politics as well as to other environments of the relevant praxis.

The diagnosis I have made does not wholly capture the reality of the jurist philosophy but what it does do is to truly describe a large part of what can be called their theoretical production. There is a common tendency between jurists that borrow fragmentarily certain philosophical tools

16 In the sense indicated by Bulygin that "the legal validity of a norm does not necessarily imply its moral validity and the moral validity of a norm does not necessarily imply its legal validity. This thesis goes back to Bentham and has been sustained by practically all the modern positivists, from Kelsen and Alf Ross to Hart and Bobbio". Naturally, Bulygin adds, "nobody denies that law and morality have many factual links: historical, social, political and linguistic. What the thesis rejects about the separation is that there should be any necessary connection (logical or conceptual) between these two social phenomena." Bulygin, Eugenio, El positivismo jurídico, México, Fontamara, 2006, p. 73. Another big name of the distinction between law and morality is Joseph Raz; however, in some of his works he has claimed that in certain contexts of the "application" of law to a specific case, the judge could resort to arguments of justice. See for example, Raz, Joseph, "Postema on Law's Autonomy and Public Practical Reasons: A Critical Comment", Legal Theory, Vol. 4, No. 1, 1998. If I am not mistaken, Bayon criticizes this razian inconsistency in: Bayón, Juan Carlos, "Derecho, convencionalismo y controversia”, en Navarro, Pablo y Redondo, Cristina (comps.), La relevancia del derecho. Ensayos de filosofía jurídica, moral y politica, Barcelona, Gedisa, 2002, pp. 57-92. For a thorough critical analysis of this type of inconsistency in Raz, see Gaido Paula, Las pretensiones normativas del derecho. Un análisis de las concepciones de Robert Alexy y Joseph Raz, Madrid, Marcial Pons, 2011.

PROBLEMA 
Esta revista forma parte del acervo de la Biblioteca Jurídica Virtual del Instituto de Investigaciones Jurídicas de la UNAM www.juridicas.unam.mx

http://biblio.juridicas.unam.mx

\section{GUILLERMO LARIGUET}

and embrace a narrow understanding of analytical philosophy, so when they endorse methodological legal positivism, they rule out moral and political philosophy because these areas are external to a self-conceived discipline which is strongly autonomous. This situation derives from a philosophy I shall call "unloaded", that is, a philosophy lacking the power to improve the task of conceptual research in law and also in nearby areas like morality and politics. In this work I wish to plea for a "reloaded" analytical legal philosophy. Unlike the English term "reloaded", the term "recargado" in Spanish - my mother tongue- connotes, at least in part, the idea of "excess", as when we say that a house is over laden with adornments. However, my idea of "reloaded" points to the thesis that legal philosophy as a discipline must be re-energized, reloaded with energy. For this reloading to be feasible, in the first part of this work, it is necessary to revisit the relationship between jurist legal philosophy and philosopher legal philosophy (section II). That is, it is necessary first to question the common reception made of Bobbio's old distinction. Second, it is necessary to revise the place the philosophy of law has in universities, especially in schools of philosophy. And this will also involve a critical look at philosophy philosophers. I shall claim that what makes a person a philosopher is not his enrolment in a university department of philosophy, but his ability to develop a philosophical perspective of the world. And this is something relatively independent of people's original training. But I shall definitely clarify this statement (section III), urging legal-philosophy jurists to look over the walls of the philosophy of law conceived in an isolated or insular fashion. This requires an exercise, an effort to fit the philosophy of law into what Willfrid Sellars called the "global intellectual landscape". ${ }^{17}$ Once the isolationism of the legal-philosophy jurists has been exposed, the following

17 Sellars, Wilfrid, "La filosofia y la imagen cientifica del hombre", in Muguerza, Javier (comp.), La concepción analitica de la filosofía, Madrid, Alianza, 1986, p. 647. 
Esta revista forma parte del acervo de la Biblioteca Jurídica Virtual del Instituto de Investigaciones Jurídicas de la UNAM www.juridicas.unam.mx

http://biblio.juridicas.unam.mx

ANALYTICAL LEGAL PHILOSOPHY RELOADED

stage is to show that what I call "methodological" legal positivism is a reflection of the legal-philosophy jurists approach; a kind of legal positivism whose outstanding feature consists of the conceptual separation between law and morality. Indeed, in the second part of the paper, an important task (section 4) is to try to determine how useful it becomes for legal-philosophy jurists - and even legal-philosophy philosophers - to adopt methodological legal positivism from a philosophical point of view. I shall here defend a middle position. I believe legal positivism may be useful as a theory rather than as a philosophy of law. But as a philosophy, it is necessary to overcome legal positivism, due to the fact that we will not be able to account for the conceptual links between legal practice and moral and political philosophy. In addition, it is necessary to study the way in which mainly legal-philosophy jurists have received analytical philosophy (section V). I will claim that what is important, once the analytical spirit has been identified, is to broaden the boundaries of this tradition and encourage the dialogue and the reception of ideas held by philosophers from different traditions.

\section{JuRist Legal Philosophy, Philosopher \\ Legal Philosophy AND Philosopher Philosophy}

As I have claimed in the introduction, I intend to critically expose the modus operandi of a certain way of conceiving the philosophy of law. Philosophy of law has been developed mainly along two lines: that of legal-philosophy jurists and that of legal-philosophy philosophers. Bobbio's distinction has been used as a way of reflecting two distinct styles of work: According to this distinction, jurists devote themselves to strictly legal issues such as the concept of illicit, administrative offence, labor risk, extra contractual liability, sanction, enforcement, embargo, etcetera, and they also know law better since they have originally been trained to casa 
Esta revista forma parte del acervo de la Biblioteca Jurídica Virtual del Instituto de Investigaciones Jurídicas de la UNAM www.juridicas.unam.mx

http://biblio.juridicas.unam.mx

\section{GUILLERMO LARIGUET}

manipulate their respective positive laws and, at best, to compare different legal systems. On the other hand, legal-philosophy philosophers have focused on issues considered to be more abstract and have not necessarily received a systematic legal education: their approach to legal matters is more abstract and serves as a basis to reflect upon issues such as the configuration of law in modernity, the mythical connection between law and the idea of sacred power, the relationship of law with facticity and moral validity, etcetera. The distinction, which appears to be parasitic to an educational-bureaucratic organization like the university may, however, be clarified. This is, the so called philosophy philosophers could perhaps, after their basic philosophical training, have been drawn to specific legal questions, while the legal-philosophy philosophers could well have been jurists but felt a preference for legal issues of greater abstraction or depth. On the other hand, we have philosophy philosophers, a label I use simply to point to those generally trained in schools of philosophy who are interested in research areas such as the philosophy of politics, morality, religion, economy, mind, language, mathematics or logic. These philosophy philosophers are sometimes indifferent to the conceptual developments raised by the reflection on law. Just as legal-philosophy jurists tend to work in an enclosed environment, so do these other philosophers, hardly concerned at all with law, viewing it disdainfully and, by extension, slyly sarcastic towards judges and lawyers who are viewed as corrupt beings, dim, foolish or ignorant of the cultural world around them. This attitude is related to a prejudice rather than an illustrated exercise of philosophical doxa. No doubt there are factors that explain this disdain, irony or indifference towards the law. The tendentially insular training of jurists, linked to the discredit they, above all judges and lawyers, command with actions lacking in moral virtue, might explain the negative attitude of philosophy philosophers. Added to this is the fact that philosophy philosophers tend to be skeptical 
Esta revista forma parte del acervo de la Biblioteca Jurídica Virtual del Instituto de Investigaciones Jurídicas de la UNAM www.juridicas.unam.mx

http://biblio.juridicas.unam.mx

ANALYTICAL LEGAL PHILOSOPHY RELOADED

about how much philosophy legal-philosophy jurists can actually master. I wish to maintain, as regards to this last point, that this skepticism is another covert form of prejudice and, as such, is rationally questionable. ${ }^{18}$ The difference between the department of philosophy and that of law, for example, is primarily a political, administrative and even bureaucratic division, and not necessarily an epistemic division. Naturally, philosophy philosophers start off with an advantage over legal-philosophy jurists: they enjoy a certain kind of integral philosophical training which might or might not have included, certain notions of legal philosophy. I say this because many schools of philosophy do not include philosophy of law as part of the curriculum, not even as part of practical philosophy reflections.

Yet the point I wish to dwell on is the following: What allows us to state that a person is a philosopher? The only attributive criterion cannot be based solely on the fact of having passed through the classrooms of a department of philosophy. Wittgenstein ${ }^{19}$ stressed that what makes us philosophers is a certain training, I would say certain ways of arguing and presenting reasons and, above all, having a nose for philosophical problems. From this point of view, the work of legal philosophers, trained in schools of law, may well be regarded as philosophical in the full sense and extension of the word "philosopher". What is more, if one takes the issue of reconstructing part of the history of Argentine analytical philosophy, one could observe that the Argentinian Society of Philosophical Analysis (SADAF) was

18 It is worth telling an anecdote passed on to me by David Martínez Zorrilla. In a meeting between Argentinian and Spanish philosophers, (SADAF and SEFA) in Madrid, in 2011, the only legal philosopher was Martinez Zorrilla himself. David was much surprised by the practically total lack of knowledge - and perhaps interest - of basic things related to the Law shown by philosopher-philosophers.

19 Scotto, Carolina, "La concepción wittgeinsteniana de los problemas filosóficos", inRivera, Silvia and Tomasini Bassols, Alejandro (comps.), Wittgenstein en Español, Buenos Aires, Ediciones de la Universidad Nacional de Lanús, 2010, pp. 13-34. 
Esta revista forma parte del acervo de la Biblioteca Jurídica Virtual del Instituto de Investigaciones Jurídicas de la UNAM www.juridicas.unam.mx

http://biblio.juridicas.unam.mx

GUILLERMO LARIGUET

set up by legal philosophers who were originally jurists, as was the case of Carrio and Rabossi. While the former excelled in the philosophy of law, the latter worked on the philosophy of mind and language, and on metaphilosophy. My former teacher Ricardo Caracciolo is an eloquent example: his contributions are not limited to the realm of the theory of law, but also to the field of metaethics where his work is greatly appreciated. And currently, my colleague Hugo Seleme, initially a jurist, is a recognized philosopher of politics and of normative ethics.

What I wish to state is that Bobbio's distinction between "a jurists' philosophy of law and a philosophers' philosophy of law" must be revised. If the distinction is taken as a separation crystallizing and fixing a closed and stagnated manner of understanding the intellectual work of legal philosophers, be they jurists or philosophers, then it needs to be reformulated. Behind a simple difference in style, the insular work of jurists ends up being justified when they claim to be philosophizing and the work of philosophers who are mostly insensitive to legal and practical issues jurists are presumably dealing with. This way of posing the distinction does not contribute to the fluidity of intellectual work on law to avoid being less stagnated in a closed form of reflection with regard to more abstract or fundamental philosophical issues, or in relation to the everyday legal matters jurists deal with. What I want to claim is that legal-philosophy jurists should always take advantage of the work made by legal-philosophy philosophers and of the general tools and views articulated by general philosophers in topics like the justification of knowledge, problems of truth, logical structure of propositions, moral justification, the status of politics, or the structure of our minds and the constitution of personal identity, to give just a few examples. Legal-philosophy philosophers and philosophy philosophers, in turn, should question their insensitivity towards - apparently pedestrian- legal issues which lack intellectual verve. A more terrestrial view, as the one offered by jurists, would surely 
Esta revista forma parte del acervo de la Biblioteca Jurídica Virtual del Instituto de Investigaciones Jurídicas de la UNAM www.juridicas.unam.mx

http://biblio.juridicas.unam.mx

ANALYTICAL LEGAL PHILOSOPHY RELOADED

be a good corrective or even a platform for empirical, conceptual or normative evidence, useful for inquiry by legal-philosophy philosophers and philosophy philosophers. ${ }^{20}$ For example, the problem of the validity of a rule, a problem which frequently occupies legal-philosophy jurists, may -by analogy - help to clarify problems regarding the validity of scientific statements or logical predicates. The importance of configuring modern law as a representation of a community's ethical life (in Hegel's style) could in turn be a precious instrument to gain an idea of the validity of legal rules that does not limit itself to notions such as pertaining to a legal system, for example, an extension to issues regarding a moral test of such rules. Take the example of philosophy philosophers' inquiry regarding the structure of mind and its relation to desires which can provide a valuable heuristic method for jurists when considering legal concepts such as intention or action.

My idea is that, notwithstanding the existence of a dominant preference for a tendentially closed form of research, ${ }^{21}$

20 In fact, if one thinks about Elster for example, one can see his reception of theoretical instruments of law in examining the rational cement of contemporary societies.

21 A symptom of this insular trend can probably be seen in some examples. For instance, the conceptual discussion analytical moral philosophers started on the concept of moral dilemmas has been going on in a refined manner for over fifty years. Let us consider for example Lemmon's article "Moral dilemmas" which appeared in '62 and which only appeared in legal theory in Atienza's texts on the tragic cases in 1997 or Zucca's texts on "constitutional dilemmas" in 2007 or Martinez Zorrilla's in 2007 with his Conflictos constitucionales, ponderación o indeterminación normativa or my 2008 text Dilemas y conflictos trágicos. The same occurs with the topic of the "ethics of virtues". Farrelly and Solum in Virtue Jurisprudence in 2006 and Amalia Amaya and Ho Hock Lai in 2012 in Virtue, Law and Justice are merited to have installed a discussion which, in analytical philosophy, goes back to the article "Modern moral philosophy" written by Anscombe in 1958. That is to say that the fact that legal philosophers get to key problems much later can be explained by this insular trend which we only dare to break every now and then. Something similar can also be indicated about moral philosophy. It wasn't until 1997 that 
Esta revista forma parte del acervo de la Biblioteca Jurídica Virtual del Instituto de Investigaciones Jurídicas de la UNAM www.juridicas.unam.mx

http://biblio.juridicas.unam.mx

\section{GUILLERMO LARIGUET}

crossing disciplinary instruments and approaches ${ }^{22}$ may have a more fluid, and therefore less stagnant impact on distinguishing between these three types of work I have briefly described above.

\section{The Philosophy of LaW and the Global INTELLECTUAL LANDSCAPE}

Another of my concerns is configured, as I said earlier, by Sellers. This philosopher - strongly influential in the works of Brandom and McDowell with his theory of the space of reasons and the link this space has with conceptual capacities and the impact this has on perception-claimed that in going about our philosophical work we should always bear in mind the idea of a "global intellectual landscape". This entails seeing how our little bailiwick fits into a more global intellectual landscape. In this sense, and as an example, the work of legal-philosophy jurists has shown little concern for placing its research within this broader intellectual landscape. This indifference has led to a closed theoretical practice, with a specialist view of a legal problem, without addressing the question of what place the problem or set of problems might occupy within a broader intellectual context. This results in specialized research offering a poor, even distorted, image of the problems being researched. For example, let us consider the work of legal-philosophy jurists on legal doctrine or so-called "legal dogmatics". What is generally noted is the existence of

Ruth Chang's Incommensurability, incomparability and pratical reason was published when, strictly speaking, the discussion on immenseness had been initiated decades earlier between the science philosophers Kuhn or Feyerabend.

22 In fact, if we appreciate the history of social sciences we notice that many theoretical achievements were reached thanks to disciplinary crosses. Consider for example the cross between Marxism and conceptual analysis (analytical Marxism), between linguistics and anthropology (French structuralism), between biology and sociology (sociobiology), and a long etcetera. 
Esta revista forma parte del acervo de la Biblioteca Jurídica Virtual del Instituto de Investigaciones Jurídicas de la UNAM www.juridicas.unam.mx

http://biblio.juridicas.unam.mx

ANALYTICAL LEGAL PHILOSOPHY RELOADED

tightly closed research on the presumably scientific nature of "legal dogmatics", which does not look at the relationship of "legal dogmatics", ad intra, with other legal disciplines such as the sociology or the history of law or, ad extra, the relationship between "legal dogmatics" and other disciplines of social sciences such as history, anthropology, etcetera. This closed ad intra and ad extra approach of the legal-philosophy jurists work likens to the image Bachelard gave of the scientist as "a miser who is content to look again and again at the same cherished gold." We do not produce the same reconstruction of "legal dogmatics" when we shut ourselves up in a specialized investigation as when we concern ourselves with seeing the relations of this discipline with other areas of law, or social sciences or humanities as a whole. For example, being able to appreciate the discussion on the descriptive or normative nature of a historian's work (Hayden White) or analyzing the discussion between materialists and interpretivists in anthropology (Harris vs. Geertz) ${ }^{23}$ may be an illuminating way of seeing how similar problems are posed in other areas of knowledge, how they are discussed or how their resolution is sought. Lacking a global idea of knowledge, the theoretical view of a problem may be very precise but at the huge cost of being blind about the place this problem has in a broader landscape, or the view of this problem in light of comparing it to, or contrasting it with, other areas of knowledge. And this blindness can give us a partial, distorted image of a problem that does not favor any dialogue between different disciplines. The result is a research that is not of interest but to a few.

IV. Methodological Legal Positivism as a Theory of Law, NOT AS A PHILOSOPHY OF Law

I suggested earlier that what I called methodological legal positivism should be better regarded as a theory of law than

23 I have analyzed these links with anthropology and history in my book Dogmática jurídica y aplicación de normas, México, Fondo de Cultura Económica, 2007. 
Esta revista forma parte del acervo de la Biblioteca Jurídica Virtual del Instituto de Investigaciones Jurídicas de la UNAM www.juridicas.unam.mx

http://biblio.juridicas.unam.mx

GUILLERMO LARIGUET

as a philosophy of law. This label I am introducing could be viewed with distrust. Is it just a matter of words to talk of a theory rather than a philosophy? What is more: some might react with confusion because they might assume the term philosophy to reveal more charm that the term theory. And after all, what importance could there be in this distinction? When I say that methodological legal positivism is more theoretical than philosophical I do not claim to draw a sharp distinction. The idea is that the way legal-philosophy jurists philosophize is more theoretical than philosophical. It is theoretical insofar as it attempts to show itself as second level research on what academic jurists do at the first level in their writing, or judges in their rulings. It is predominantly dense research because of its proximity to legal problems and concepts in the way these are understood by dogmatic jurists or judges. The work of a legal-philosophy jurist is that of a "theorist of law" who reconstructs, on a second, presumably clearer level, markedly legal concepts and problems, such as the concepts of illicitness, sanction, nullity, legal validity, constitutionality, etcetera. It is a theoretical endeavor, which may resort to instruments of analysis such as disambiguation, detection of vagueness, or tracing family likeness, etcetera. But this is a task that can be relatively done - I repeat, only relatively - without philosophical concepts forged by philosophy philosophers. Here I am mainly focusing on the modus operandi of legal-philosophy philosophers and jurists, especially when they embrace methodological legal positivism. This does not mean that we may encounter a "more philosophical" legal positivism when it is defined with more abstract strategies of reflection and conceptual development by legal-philosophy philosophers. However, in both cases, - jurist legal philosophy and philosopher legal philosophy-, there is a certain inclination to isolationism with regard to practical philosophy. In other words, the distinction I am making between theory and philosophy, or between legal-philosophy jurists and legal-philosophy philosophers is much less dichotomous and 
Esta revista forma parte del acervo de la Biblioteca Jurídica Virtual del Instituto de Investigaciones Jurídicas de la UNAM www.juridicas.unam.mx

http://biblio.juridicas.unam.mx

closed in actual fact than the analytical distinction I make indicates in the abstract.

The task of positivist legal philosophy jurists also endeavors to show that their theoretical reflection is neutral from a normative point of view. And this claim is ingenuous -and this is admitted by virtually all legal positivists- because the selection of the problems and of their treatment already assumes the election of epistemic options such as a clear, simple and coherent explanation; options which are normative. But it is also ingenuous with regard to other types of normativity or prescriptive, axiological or ideological commitments. For example, from the moment a legal positivist uses the term "authority" in his vocabulary, he is inoculating his methodological design with a concept historically charged with moral, political and ideological components that are impossible to sublimate or to consider in the abstract. This term, let there be no doubt, will not only have a bearing on the way the theoretical object "law" is delimited, but will also decisively determine the appropriate conceptual form it must be characterized with. Including this term, therefore, cannot preserve the theoretical neutrality sought and leave legal positivism's methodological consistency unaffected.

On the other hand, the idea that it is possible to transfer a legal term, or one from common sense, to a pure environment in which ambiguity and inaccuracy have completely disappeared distorts the relevance of philosophical analysis. It is an idea of rational reconstruction that delimits a concept removing it from its original historical, ideological and semantic conditions, removing it excessively from the substance of the practices in which these concepts operate. In more axiom based areas such as logic and mathematics there is greater awareness of the indeterminacy of language and its historical trajectory. Contrary to this idea which is closer to practices, the traditional use of rational reconstruction, for example to place the concept of regulatory gap in a pure, aseptic laboratory, ends up by producing a 
Esta revista forma parte del acervo de la Biblioteca Jurídica Virtual del Instituto de Investigaciones Jurídicas de la UNAM www.juridicas.unam.mx

http://biblio.juridicas.unam.mx

\section{GUILLERMO LARIGUET}

questionable investigation of the concept. A more sensitive look at conceptual issues such as those posed by jurists in their practices - practices affected by historical, cultural and ideological conditionings - would lead us to doubt, about a clear distinction as the one between normative and axiological gaps. To what extent should an absent norm in a legal order, and one that produces a gap, not be in the order in question? And to what extent does this "should be" have an axiological or ideological ingredient that dilutes the limiting border between normative and axiological gaps?

On the other hand, I prefer to talk about a theory rather than a philosophy because I understand that philosophy has a more direct commitment to the relationship between law, morality and politics. However, the methodological difference between law and morality, drawn up by methodological legal positivism, contributes to making the problem of normativity fall outside the boundaries of the philosophy of law thus conceived. This is a problem a legal positivist has as a supporter of legal positivism, independently of the type of philosophical training he has. However, the problem is heightened by the isolationist type of training I referred to earlier.

If one has a historical perspective of the concepts and sees them sub specie aeternitatis, one notices that what was understood as philosophy of law in the $18^{\text {th }}$ and $19^{\text {th }}$ centuries was a systematic reflection on the law in connection with morality. This was disrupted by methodological legal positivism. This disruption was initially produced by Kelsen with his idea of a strong autonomy of law with regard to other human disciplines. This primarily epistemic issue then shifted with Hart towards a normative question of the authority of law. Indeed, the problem for legal positivism, since Hart, was to account for the authority of law. ${ }^{24}$ If law

24 This was not a problem for the nineteenth-century jurist Austin for whom the bindingness of law rested on the fear of being sanctioned. It is curious to observe that this places the addressee of the norm in the same place as Kohlberg placed children under 9 who, in the context of a 
Esta revista forma parte del acervo de la Biblioteca Jurídica Virtual del Instituto de Investigaciones Jurídicas de la UNAM www.juridicas.unam.mx

http://biblio.juridicas.unam.mx

has authority it means it is normative. If it is normative, this means, among other things, that it gives us reasons to act in spite of our personal balance of reasons. From the very moment methodological legal positivism considered the problem of authority (first in the Hartian and then the Razian versions) I believe the confusion began. The pleiad of legal positivists, now inclusive or exclusive, has brought confusion, not clarity. ${ }^{25} \mathrm{I}$ am of the opinion that methodological positivism is incapable of accounting for the authority or normativity of law. To put it simply, to do so is not part of its program. And to persist in using terms like authority, normativity, inclusive or presumably exclusive legal positivism implies what Internet users call "second order blindness". Indeed, legal positivists fail to see that they do not $\mathrm{see}^{26}$ the problem of legal authority and normativity. Every time the legal positivist includes the topic of authority he runs the serious risk of wrecking himself against a rock leading to self-destruction ${ }^{27}$ or to the production of a methodologically incoherent program. As long as legal positivists include the issue of law's authority into its research realm, legal positivism loses clarity, which is an important desideratum for analytical philosophers. Every time a legal positivist talks of the authority of law we encounter a double inconvenience. Either his explanation is a autopoietic one, that is, a la Luhmann, explaining the legal from the legal, which leaves the road open to paradoxes resulting from

pre-conventional morality, obeyed for fear of punishment without the slightest reflection on the goodness, correctness or justice of what the authority said. This places legal philosophy before a dilemma: either we obey the law as children do, or we need a notion of authority; a notion which, because of its commitment to practical philosophy, removes us from the framework of methodological positivism.

25 This has been suggested by Navarro, Pablo, among others. "Las tensiones conceptuales en el positivismo jurídico", Doxa. Cuadernos de Filosofía del Derecho, Alicante, núm. 24, 2001, pp. 133-163.

26 I thank René González de la Vega for bringing my attention to this fact.

27 Navarro, op. cit. 
Esta revista forma parte del acervo de la Biblioteca Jurídica Virtual del Instituto de Investigaciones Jurídicas de la UNAM www.juridicas.unam.mx

http://biblio.juridicas.unam.mx

GUILLERMO LARIGUET

normative self-reference. Or explaining the notion of authority results in a discussion about morality that a legal positivist is eager to deny. The latter makes a legal positivist an under-cover theorist of natural law and not a genuine legal positivist, just what Ross blamed Kelsen for when he questioned the consistency of the Kelsenian model that resorted to the mysterious notion of mandatory force. It may be correct to say, like David Enoch, 28 that the law only has an instrumental value as a reminder or trigger of moral reasons which are ultimately genuine robust reasons. However, this approach which would recover the instrumental value of law, and which would be in line with legal positivism I have called "methodological", has two flaws. The first is that many legal positivists (Raz for example) would not feel comfortable with the purely instrumental value of the law which may soon lead to the idea of the acceptance of legal reasons for prudential and not categorical reasons. Of course, when we say categorical we are already in front of the same problem of blurring the identity of legal positivism because we are again opening a window through which the winds of morality sneak in. The second is that the idea of law as a "reminder" of morality clouds our vision regarding the nature of this mechanism. For example, when I set a reminder in my cell phone, what software does that reminder belong to? I'm afraid the reminder can be seen as a box (the law) which is within a larger box (morality). In short, the ultimate reasons for acting, the genuine ones, would be moral, so, would it be rational to obey legal rules? Verónica Rodriguez Blanco 29 is hounded by this question. For her, the problem is how to account for the normativity of law,

28 Enoch, David, "Reason-giving and the Law", Oxford Studies in Philosophy of Law, edited by Green, Leslie and Leiter, Brian, Oxford, Oxford University Press, 2011.

29 Rodríguez Blanco, Verónica, "Reasons in Action vs. Triggering-Reasons. A Reply to Enoch on Reason-Giving and Legal Normativity", Problema. Anuario de Filosofía y Teoría del Derecho, México, núm. 7, 2013, pp. 3-25. 
Esta revista forma parte del acervo de la Biblioteca Jurídica Virtual del Instituto de Investigaciones Jurídicas de la UNAM www.juridicas.unam.mx

http://biblio.juridicas.unam.mx

ANALYTICAL LEGAL PHILOSOPHY RELOADED

admitting that it gives us reasons to act by cancelling our own reasons and, concurrently showing that such (heteronomous) reasons do not undermine our moral autonomy and practical intentionality. She claims that the normative core of legal rules resides in the fact that they can be conceived as clauses "in the guise of the good". But when we introduce the predicate "good", problems emerge. If "good" points to a moral notion (not just an instrumental one as von Wright has shown) then it cannot be coherent to account for normativity in the guise of the good and at the same time call oneself a legal positivist, as René González de la Vega rightly points out. ${ }^{30}$ One has to abandon legal positivism, if one wants to become involved in the problem of normativity. Legal positivism may be a valuable instrument for theorizing about the law, dealing, for example, with different notions of validity or efficacy of rules, the presumably systematic structure of law, or fundamental legal concepts. My proposal, despite of what has been said, is that a legal-philosophy jurist who decides to practice a variant of methodological legal positivism can make things more interesting. I am going to make a statement that may sound provocative, to my regret: If a legal-philosophy jurist wishes to philosophize, he must give up the conceptual separation between law and morality. As Dan Priel ${ }^{31}$ has said, he must show the holistic relations mediating between the notions of validity, content, normativity and legitimacy of law. From the moment a legal-philosophy philosopher does this, like the chrysalis, he will rend his shell and open up to the vivifying experience of conceiving himself as a practical philosopher. However, an objection could be raised, namely, that a legal-philosophy jurist or a legal-philosophy philosopher could still defend a conceptual dichotomy between law and morality with arguments gleaned from the reservoir of prac-

30 The paradox of normativity of law. A comment on Rodríguez Blanco's solution, Problema. Anuario de Filosofia y Teoría del Derecho, México, núm. 7, 2013, pp. 63-79.

31 “The Place of Legitimacy in Legal Theory", McGill Law Journal, 2011. 
Esta revista forma parte del acervo de la Biblioteca Jurídica Virtual del Instituto de Investigaciones Jurídicas de la UNAM www.juridicas.unam.mx

http://biblio.juridicas.unam.mx

\section{GUILLERMO LARIGUET}

tical philosophy, but this is not what I have in mind. My idea of practical philosophy is holistic and connectionist. I sincerely believe that political, moral, legal, or religious philosophies - to give a few characteristic examples- have holistic connections between them that repel the allegedly analytical separation that legal positivists might defend. A legal positivist is either a poor practical philosopher because he does not capture the holistic nature of this area of philosophical knowledge, or on the other hand, he is not a practical philosopher at all.

A paradigmatic example of what I have in mind is the work in practical philosophy undertaken by Ronald Dworkin. Dworkin has always sought the way to communicate legal philosophy and constitutional jurisprudence with moral philosophy, political philosophy, epistemology and metaphysics in his reflections. ${ }^{32}$ These disciplines are intertwined every time Dworkin discusses a problem. Unlike the Kelsenian view, his view is not schizophrenic. It may be mistaken, but he does not confuse treating the topic of the authority and normativity of law the way Hartians and Razians do when they vainly claim to do so within legal positivism, where the expressions "soft" or "inclusive" or "exclusive" have brought about more confusion than clarity.

I think a practical philosopher is one who articulates a conceptual investigation looking with curiosity, fresh surprise, with an effort for creativity, at the connections mediating the different areas that make up practical experience (law, morality, politics, religion, and etcetera). I do not expect this definition to persuade theorists of law to give their task up completely. It has produced outcomes that are relevant to the law. However, this technical work should be open to influences from channels of practical philosophy to produce images of law appropriate to its complexity; a complexity which, on the other hand, has a lot to do with the fact that the law is a rare combination of will and practical

32 Let his Justice for Hedgehogs, Cambridge, Mass., Belknap Press, 2011 , serve as summary of all his practical philosophy. 
Esta revista forma parte del acervo de la Biblioteca Jurídica Virtual del Instituto de Investigaciones Jurídicas de la UNAM www.juridicas.unam.mx

http://biblio.juridicas.unam.mx

ANALYTICAL LEGAL PHILOSOPHY RELOADED

reason, history and the search for permanence, legislation and argumentative articulation, ${ }^{33}$ etcetera. A practical philosopher should take advantage of some of the components produced by legal theorists, with the caveats already mentioned. These components can help the practical philosopher with concrete legal issues that enable a discussion of other general philosophical positions.

\section{Analytical Legal Philosophy Revisited}

As I pointed out in the introduction to this paper, legal philosophers, especially those who are jurists, have a partial reception not only of philosophy but also of one of its manifestations, namely analytical philosophy. This reception got distorted up to the point where its claims became a Vaticanist index librorum prohibitorum. According to this index it is embarrassing for analytical philosophers to refer -let alone publish - texts in which Hegel, Nietzsche, Weil, Foucault, Ricoeur, and so on, are quoted. ${ }^{34}$ This way of understanding philosophical analysis is not necessarily shared by mainstream philosophy. It is also a way of approaching the subject which is not greatly descriptive of the very history of analytical philosophy. There are numerous communications between analytical philosophers and authors who belong to other traditions. Let us consider, for example, Wolfgang Detel's analytical work on the ethics of Foucault and its links to the ancient world. And why not

33 Bix, Brian, "Voluntad y razón: la verdad en el derecho natural, el derecho positivo y la teoría jurídica", trans. by Guillermo Lariguet and Roberto Parra, in Teoría del derecho: ambición y límites, Madrid, Marcial Pons, 2006.

34 David Martinez Zorrilla also remarked that in the meeting of analytical philosophers he took part in in Madrid, the term "continental philosopher" was used insultingly. Which means that this closed and reactionary spirit can also be attributed to certain analytical philosopher-philosophers. Perhaps this sectarian attitude is partly explained in that these philosophers have remained as captives of logical positivism and their narrow way of understanding philosophy and meaningful sentences. 
Esta revista forma parte del acervo de la Biblioteca Jurídica Virtual del Instituto de Investigaciones Jurídicas de la UNAM www.juridicas.unam.mx

http://biblio.juridicas.unam.mx

\section{GUILLERMO LARIGUET}

consider Bernard Williams' sympathy for Nitzschean genealogical research, or Redding's recovery of Hegel, or even Nussbaum's interest in poetic justice and her contributions to literature, etcetera. Meanwhile more and more continental philosophers —or originally continental- like Apel ${ }^{35}$ or Tughendat, ${ }^{36}$ to give just a few examples, showed a receptivity of analytical elements (the "linguistic turn" in Apel's case) and the transformation of metaphysical intuitions of Aristotle and Heidegger to analytical semantics in Tughendat's case.

This index librorum prohibitorum I have referred to is something like an unwritten rule in the corridors of certain universities or research departments. This type of forma mentis was forged according to a certain legal philosophy, what Rabossi, not long before his death, called the "philosophical canon". ${ }^{37}$ This canon has operated, sociologically speaking, as a prerequisite for access to what Bourdieu ${ }^{38}$ called "state nobility"; the condition of nobility of certain intellectuals in the jurisprudential domain. I would like to clarify that I continue to vindicate a personal commitment to analytical philosophy. But this commitment is quite apart from certain commonplaces that can be found in this reception of philosophical analysis much closer, in a certain manner, to the dawn of analytical philosophy represented in the past by the Vienna Circle. Below, as a coda, I suggest some questions philosophical analysis should cover in the practical realm, that is, in that which concerns not only the law and morality, but also politics and religion. They are

35 See De Santiago Guervós, Luis Enrique, "El giro pragmático hermenéutico de la filosofia actual desde la perspectiva trascendental de K. O. Apel”, Contrastes. Revista Interdisciplinar de Filosofía, núm. 1, 1996, pp. 285-308.

36 Tughendat, Ernst, Introducción a la filosofía analitica, Barcelona, Gedisa, 2003.

37 Rabossi, Eduardo, En el principio Dios creó el canon. Biblia berolinensis, Barcelona, Gedisa, 2009.

38 Bourdieu, Pierre, Nobleza de Estado. Educación de élite y espíritu de cuerpo, México, Siglo XXI Editores, 2013. 
Esta revista forma parte del acervo de la Biblioteca Jurídica Virtual del Instituto de Investigaciones Jurídicas de la UNAM www.juridicas.unam.mx

http://biblio.juridicas.unam.mx

ANALYTICAL LEGAL PHILOSOPHY RELOADED

suggestions and, as such, require greater subsequent reflexive development.

The first issue is the following. The dichotomy - presumably exclusive and exhaustive - that certain analytical philosophers have used to draw a distinction between declarative and expressive language must be questioned if it is formulated in those terms. If this dichotomy means that philosophical language must be exclusively declarative -on account of its commitment to the search for truth- while expressive language has to be eliminated - because it does not express any kind of true knowledge - then the distinction should be rejected. For example, philosophers, like Jon Elster, who use analytical tools, do not hesitate to talk about "sour grapes" to refer to problems of rationality. The same occurs with philosophers such as Isaiah Berlin or Ronald Dworkin who - following the path laid down by the ancient poet Archilochus - talk about "foxes" and "hedgehogs" to convey, in an exemplary manner, the problem of monism and pluralism in matter of values. Strictly speaking, as Ortiz Millán ${ }^{39}$ has shown, literature and poetry for example, can embody a form of knowledge that reveals some aspects of our social and moral world. It is therefore not true that certain manifestations of poetry should be discarded because of a narrow-minded analytical aversion. For example, a renowned analytical philosopher like Thomas Moro Simpson, ${ }^{40}$ in Análisis filosófico, starts a review essay with a poem which attempts to be a "brief essay of the psychology of perception". In one stanza he poses the problem of ambiguity from the observer's perspective with greater vividness than one favoured by cold conceptual explanation. He reveals the problem of the ambiguity of perception, as Wittgenstein formulated it, when he says:

39 Ortiz Millán, Gustavo, "El cognoscitivismo poético. ¿Qué conocemos a través de la poesía?”, Convivium. Revista de Filosofía, núm. 23, 2010.

40 "El dibujo y la mirada", Análisis Filosófico, Buenos Aires, XXXI, 2011 , p. 1 . 
Esta revista forma parte del acervo de la Biblioteca Jurídica Virtual del Instituto de Investigaciones Jurídicas de la UNAM www.juridicas.unam.mx

http://biblio.juridicas.unam.mx

\section{GUILLERMO LARIGUET}

I've been looking at it for a while, And if I don't stop looking

It sometimes looks like a duck

And others like a rabbit.

What I have just pointed out serves a preamble to defend the idea that philosophy can improve its work ${ }^{41}$ if it complements itself with expressive and metaphorical ingredients. In this sense, as with Lakoff and Johnson, ${ }^{42}$ I think metaphors have a cognitive value. It is not only a fact that they are the substrate of our everyday modus vivendi, but also that they help to structure our experience and perception, conceptually speaking. Therefore a metaphor used by a philosopher may be a vivid manner of expressing an idea with greater sharpness than if it was done in a purely literal manner, as Davidson suggested.

The second aspect I wish to bring to attention is the presumably "neutral" nature of analytical work. This is the idea that the analytical philosopher designs a machinery to forge concepts, to examine their logical relationships, to clarify the manner in which we use language, etcetera. But one can assume that this machinery is purely conceptual and descriptive, in the sense that it clarifies the bricks that constitute our practices, unraveling confusions language produces when it goes beyond its axes, as Wittgenstein claimed. I am not sympathetic to this manner of reconstructing philosophical analysis. In other words, I do not consider philosophical work should be reduced to these tasks. If it is true that, as Ayer said in a prologue to a work by Nowell Smith, we must distinguish between the moralist -for instance the litterateur - and the moral philosopher, because the former prescribes and the latter just describes, I must say, as Nowell Smith, that I do not agree with draw-

41 And make us better philosophers, as Cristian Fatauros once said.

42 Lakoff, George and Mark Johnson, Metaphors We Live By, Chicago, Chicago University Press, 1986. 
Esta revista forma parte del acervo de la Biblioteca Jurídica Virtual del Instituto de Investigaciones Jurídicas de la UNAM www.juridicas.unam.mx

http://biblio.juridicas.unam.mx

ANALYTICAL LEGAL PHILOSOPHY RELOADED

ing a strict line between both tasks. ${ }^{43}$ For example, the litterateur also describes. Let us think, for instance, about the novels in which Zola describes his characters' psychological aspects and social and historical environment in detail. With regard to moral philosophy, von Wright, a champion of analysis, already claimed in The Varietés of goodness, ${ }^{44}$ that the philosopher's work, although conceptual, is also normative. Normative in the sense that a particular structure of our concepts of correctness, goodness, etcetera, will not only indicate the manner in which we organize our experiences; it will also have an impact on what we should think, feel and do. This is because moral concepts are characteristically normative concepts. For example, Korsgaard 45 has claimed that moral philosophers are interested not only in explaining the evolutionary manner in which we have managed to acquire particular moral concepts, thus fulfilling the epistemic requirement of explicative or empirical adaptation, but also in normative questions, and when we do, we are involved in a normative or justificatory task. In a similar vein, the pragmatic philosopher Faerna, ${ }^{46}$ in analyzing a paper where Searle takes the concept of human rights apart from a purely neutral position, argues that this is impossible. Indeed, he points to the manner in which Searle's conception impacts directly on the substantive debates we hold on rights, that is to say, his conceptual ensemble has "practical friction". To think the philosopher should only content himself, as Ricardo Reis de Pessoa said, with contemplating the world, is to misunderstand philosophical work in all of its complexity.

43 D. D., Raphael, “Can Literature Be Moral Philosophy?”, New Literary History, vol. 15, No. 1, 1983, p. 3.

44 Las variedades de lo bueno, translated by González Lagier and Victoria Roca, 2010, Marcial Pons, Madrid, pp. 39-40.

45 Korsgaard, Christine, Las fuentes de la normatividad, trans. by Fabiola Rivera, México, UNAM, 2000, p. 22.

46 Faerna, Angel, "Ontología social y derechos humanos en John Searle”, Análisis Filosófico, Buenos Aires, vol. XXXI, num. 2, 2011, p. 115. 
Esta revista forma parte del acervo de la Biblioteca Jurídica Virtual del Instituto de Investigaciones Jurídicas de la UNAM www.juridicas.unam.mx

http://biblio.juridicas.unam.mx

\section{GUILLERMO LARIGUET}

Philosophical work cannot be viewed as a wheel that rotates around itself; rather, it should be viewed as a set of concepts that guide us in our lives, communicating to us its sense and the way we should lead a satisfactory life.

The third aspect I wish to discuss is a defense of a less insular work done by practical philosophy itself. This implies the need to reinforce not just interdisciplinarity -encouraging an overlapping between moral philosophy and other philosophical disciplines- but also interdiscipline, sponsoring a rendezvous between philosophy and disciplines such as literature, history, psychology and economy. What I am pointing out does not detract from the relative independence of the moral philosophy John Rawls ${ }^{47}$ placed in moral theory as a discipline which compares and examines substantive moral conceptions. But philosophy doubtless benefits and obtains a more complex view from linking not only with the Philosophy of mind, Philosophy of language, Epistemology or its closest relatives like political, religious or legal philosophy. It also benefits from links with other disciplines, such as history for example, the history which is the background of many novels, and history as a relatively autonomous theoretical discipline. This not only produces a douse of humanism for philosophy as Bernard Williams has claimed, ${ }^{48}$ but also dispels the classic objection directed against analytical philosophy according to which it resorts to ahistorical, fossilized explanations. As Mie has shown, ${ }^{49}$ concepts are obtained from a historical background that traces what Hermeneutists call a "horizon of understanding". The lack of history in philosophy robs it of a sense of past, as Bernard Williams once said. It also

47 Rawls, John, "The Independence of Moral Theory", in Collected Papers, edited by Samuel Freeman, Cambridge, Mass., Harvard University Press, 2001, pp. 286 and ff.

48 Williams, Bernard, La filosofía como una disciplina humanística, México, FCE, 2011.

49 Mié, Fabián, "El lenguaje histórico-conceptual de la filosofia", Ideas y Valores, Bogotá, núm. 140, 2009, pp. 143-172. 
Esta revista forma parte del acervo de la Biblioteca Jurídica Virtual del Instituto de Investigaciones Jurídicas de la UNAM www.juridicas.unam.mx

http://biblio.juridicas.unam.mx

ANALYTICAL LEGAL PHILOSOPHY RELOADED

justifies the ghostly presence of certain theories that continue to be defended in spite of having been questioned by history. This could be the case with methodological legal positivism, from the analytical tradition, which continues to be defended regardless of current evidence which indicates the prevailing presence of morality in law, thus breaking the strict separation between the law and morality.

The last aspect I wish to point out is the following. It is traditionally held that analytical philosophy is constituted on the basis of conceptual distinctions.

I agree that distinguishing is a way of achieving greater clarity. However, insistence on non-stop distinguishing can blind us to the close relationships between concepts. For example, the distinction between literature and philosophy, between reason and emotion, should be made with extreme caution. If distinctions blind us to certain relationships that occur between concepts, as Hegelians have thought, we may be led far from the problems we wish to clarify. More pragmatic philosophers like Putnam have also been aware of this when examining the collapse of the dichotomy between fact and value. The collapse occurs when we draw the scope of the fact-value distinction in its precise terms, that is, when the dichotomy serves to clarify the concepts but not to estrange them with an insurmountable gap which prevents us from seeing productively that they are actually related on the ontological plane.

VI. BIBLIOGRAPHY

AmAYA, Amalia and Ho Hock, Lai (eds.), Law, Virtue and Justice, Oxford, Hart Publishing, 2012.

Anscombe, G. E. M., "Modern Moral Philosophy", Philosophy, vol. 33, No. 124, January 1958.

ATIEnZA, Manuel, "Los límites de la interpretación constitucional. De nuevo sobre los casos trágicos", Isonomía. 
Esta revista forma parte del acervo de la Biblioteca Jurídica Virtual del Instituto de Investigaciones Jurídicas de la UNAM www.juridicas.unam.mx

http://biblio.juridicas.unam.mx

GUILLERMO LARIGUET

Revista de Teoría y Filosofía del Derecho, núm. 6, abril de 1997.

BAYÓN, Juan Carlos, "Derecho, convencionalismo y controversia", in NAVARRO, Pablo y REDONDO, Cristina (comps.), La relevancia del derecho. Ensayos de filosofia jurídica, moral y política, Barcelona, Gedisa, 2002.

BIX, Brian, "Voluntad y razón: la verdad en el derecho natural, el derecho positivo y la teoría jurídica", trans. by Guillermo Lariguet and Roberto Parra, in Teoría del derecho: ambición y limites, Madrid, Marcial Pons, 2006.

BOURDIEU, Pierre, Nobleza de Estado. Educación de élite y espíritu de cuerpo, México, Siglo XXI editores, 2013.

Bulygin, Eugenio, El positivismo jurídico, México, Fontamara, 2006.

Bulygin, Eugenio, “... speech when receiving the honoris causa PhD from the University of Alicante", Academia. Revista sobre Enseñanza del Derecho, Year 6, No. 12, 2008.

CHANG, Ruth (ed.), Incommensurability, Incomparability, and Practical Reason, Harvard, Harvard University Press, 1997.

DwORKIN, Ronald, Justice for Hedgehogs, Cambridge, Mass., Belknap Press, 2011.

Elster, Jon, Juicios Salomónicos, Barcelona, Gedisa, 1998.

ENOCH, David. "Reason-giving and the Law", Oxford Studies in Philosophy of Law, edited by Green, Leslie and Leiter, Brian, Oxford, Oxford University Press, 2011.

FAERNA, Angel, "Ontología social y derechos humanos en John Searle”, Análisis Filosófico, Buenos Aires, Vol. XXXI, núm. 2, 2011.

FARRELly, Colin and SOlum, Lawrence (eds.), Virtue Jurisprudence, Basingstoke, England, Palgrave Macmillan, 2007. 
Esta revista forma parte del acervo de la Biblioteca Jurídica Virtual del Instituto de Investigaciones Jurídicas de la UNAM www.juridicas.unam.mx

http://biblio.juridicas.unam.mx

ANALYTICAL LEGAL PHILOSOPHY RELOADED

GAIDO, Paula, Las pretensiones normativas del derecho. Un análisis de las concepciones de Robert Alexy y Joseph Raz, Madrid, Marcial Pons, 2011.

GONZÁLEZ DE LA VEGA, René, "The Paradox of Normativity of Law. A Comment on Rodriguez Blanco's Solution", Problema. Anuario de Filosofía y Teoria del Derecho, México, núm. 7, 2013.

GUASTINI, Riccardo, Distinguiendo. Estudios de teoria y metateoría del derecho, Barcelona, Gedisa, 1999.

HABERMAS, Jürgen, Feasibility and Validity. On Law and the Democratic Rule of Law in Terms of the Theory of Discourse, Madrid, Trotta, 1998.

KORSGAARD, Christine, Las fuentes de la normatividad, trans. by Fabiola Rivera, México, UNAM, 2000.

LAKOFF, George and JoHnson, Mark, Metaphors We Live By, Chicago, Chicago University Press, 1986.

LARIGUET, Guillermo, "La aplicabilidad del programa falsacionista de Popper a la ciencia jurídica", Isonomía. Revista de Teoría del Derecho, México, núm. 17, 2002.

LARIGUET, Guillermo, Dogmática jurídica y aplicación de normas, México, Fontamara, 2007.

LARIGUET, Guillermo, Problemas del conocimiento juridico, Buenos Aires, Ediar, 2008.

LARIGUET, Guillermo, Dilemas y conflictos trágicos, Lima-Bogotá, Palestra-Temis, 2008.

LAUDAN, Larry and CRUZ PARCERO, Juan Antonio (comps.), Prueba y estándares de prueba en el derecho, México, UNAM, Instituto de Investigaciones Filosóficas, 2010.

LEMOn, E. J., "Moral Dilemas", Philosophical Review, vol. 71, No. 2, 1962.

MACKIE, John, Ethics. The Invention of Good and Bad, Barcelona, Gedisa, 2000. 
Esta revista forma parte del acervo de la Biblioteca Jurídica Virtual del Instituto de Investigaciones Jurídicas de la UNAM www.juridicas.unam.mx

http://biblio.juridicas.unam.mx

GUILLERMO LARIGUET

MARTÍNEZ ZORRILlA, David, Conflictos constitucionales, ponderación e indeterminación: normativa, Madrid, Marcial Pons, 2007.

Mié, Fabián, "El lenguaje histórico-conceptual de la filosofia”, Ideas y Valores, Bogotá, núm. 140, 2009.

Moro Simpson, Thomas, "El dibujo y la mirada", Análisis Filosófico, Buenos Aires, XXXI, 2011.

NAVARRO, Pablo, "Tensiones conceptuales en el positivismo jurídico", Doxa. Cuadernos de Filosofía del Derecho, Alicante, núm. 24, 2001.

ORTIZ Millán, Gustavo, "El cognoscitivismo poético. ¿Qué conocemos a través de la poesia?", Convivium. Revista de Filosofía, núm. 23, 2010.

PRIEL, Daniel, "The Place of Legitimacy in Legal Theory", McGill Law Journal, 2011.

PRIEL, Daniel, "H. L. A. Hart and the Invention of Legal Philosophy", Problema. Anuario de Filosofía y Teoria del Derecho, México, núm. 5, 2011.

RABossi, Eduardo, En el principio Dios creó el canon. Biblia berolinensis, Barcelona, Gedisa, 2009.

RAPHAEL, D. D., "Can literature be moral philosophy?”, New Literary History, vol. 15, No. 1, 1983.

RAWls, John, Teoría de la justicia, México, Fondo de Cultura Económico, 1995.

RAWLS, John, "The Independence of Moral Theory", Collected Papers, edited by Samuel Freeman, Cambridge, Mass., Harvard University Press, 2001.

RAZ, Joseph, "Postema on Law's Autonomy and Public Practical Reasons: A Critical Comment", Legal Theory, Vol. 4, No. 1, 1998.

REAL ALCALÁ, José Alberto del, "La construcción temática de la filosofia del derecho de los juristas", Problema. 
Esta revista forma parte del acervo de la Biblioteca Jurídica Virtual del Instituto de Investigaciones Jurídicas de la UNAM www.juridicas.unam.mx

http://biblio.juridicas.unam.mx

ANALYTICAL LEGAL PHILOSOPHY RELOADED

Anuario de Filosofía y Teoría del Derecho, México, núm. 4, 2010.

Rodríguez Blanco, Veronica, "Reasons in Action vs. Triggering-Reasons. A Reply to Enoch on Reason-Giving and Legal Normativity", Problema. Anuario de Filosofía y Teoría del Derecho, México, núm. 7, 2013.

SANTIAGO DE GUERVÓs, Luis Enrique, "El giro pragmático hermenéutico de la filosofia actual desde la perspectiva trascendental de K. O. Apel", Contrastes. Revista interdisciplinar de Filosofía, núm. 1, 1996.

SANTOS, Boaventura de Sousa, Poderá o direito ser emancipatório?, Faculdade de Direito e Fundação Boiteux Vitória, 2007.

ScotTo, Carolina, "La concepción wittgeinsteniana de los problemas filosóficos", in RIVERA, Silvia and TOMASINI BASSOLS, Alejandro (comps.), Wittgenstein en Español, Buenos Aires, Ediciones de la Universidad Nacional de Lanús, 2010.

SELLARS, Wilfrid, "La filosofia y la imagen científica del hombre", in MUGUERZA, Javier (comp.), La concepción analitica de la filosofía, Madrid, Alianza, 1986.

Toulmin, Stephen, The Uses of Argument, Cambridge, Cambridge University Press, 2003.

TUGHENDAT, Ernst, Introducción a la filosofía analitica, Barcelona, Gedisa, 2003.

VON WRIGHT, Henrik, Las variedades de lo bueno, trans. by González Lagier and Victoria Roca, Madrid, Marcial Pons, 2010.

WILliams, Bernard, La filosofia como una disciplina humanistica, México, Fondo de Cultura Económica, 2011.

ZIZEK, Slavok, The Most Sublime of the Hysterics, Buenos Aires, Paidós, 2011.

ZUCCA, Lorenzo, Constitutional Dilemmas. Conflicts of Fundamental Legal Rights in Europe and the USA, New York, Oxford University Press, 2007. 